\title{
Correction: SIRT1 Is a Regulator in High Glucose-Induced Inflammatory Response in RAW264.7 Cells
}

\section{The PLOS ONE Staff}

The first four authors, Yanhui Jia, Zhao Zheng, Yunchuan Wang, and Qin Zhou, should be noted as contributing equally to this work. Weixia Cai is not included in this group of equal contributors.

\section{Reference}

1. Jia Y, Zheng Z, Wang Y, Zhou Q, Cai W, Jia W, et al. (2015) SIRT1 Is a Regulator in High Glucose-Induced Inflammatory Response in RAW264.7 Cells. PLoS ONE 10(3): e0120849. doi: 10.1371/journal. pone.0120849 PMID: 25793995

\section{G OPENACCESS}

Citation: The PLOS ONE Staff (2015) Correction: SIRT1 Is a Regulator in High Glucose-Induced Inflammatory Response in RAW264.7 Cells. PLoS ONE 10(5): e0127605. doi:10.1371/journal. pone.0127605

Published: May 4, 2015

Copyright: $\odot 2015$ The PLOS ONE Staff. This is an open access article distributed under the terms of the Creative Commons Attribution License, which permits unrestricted use, distribution, and reproduction in any medium, provided the original author and source are credited. 